\title{
Living Qur'ān: \\ Sebuah Pendekatan Baru dalam Kajian Al-Qur'ān (Studi Kasus di Pondok Pesantren As-Siroj Al-Hasan Desa Kalimukti Kec. Pabedilan Kab. Cirebon)
}

\author{
Didi Junaedi ${ }^{1}$
}

\begin{abstract}
This article focuses its study on the method of Living Qur'an as a new approach in the study of the Qur'an. Living Qur'an is an academic study on variety of social activities related with the presence of the Qur'ān or the presence of the Qur'ān in a certain Muslim community. Living Qur'an can also be interpreted as "the living text of the Qur'an in a community." This approach tries to portray the interaction process of a community with the Qur'an, not only in the understanding of its text, but more imporantly on the implementation of Qur'anic text in the daily life. This implementation then materializes in community's daily life.
\end{abstract}

\begin{abstract}
Abstrak
Artikel ini memfokuskan kajian tentang metode Living Qur'ān sebagai sebuah pendekatan baru dalam kajian al-Qur'ān. Living Qur'ān adalah kajian atau penelitian ilmiah tentang berbagai peristiwa sosial terkait dengan kehadiran al-Qur'ān atau keberadaan al-Qur'ān di sebuah komunitas muslim tertentu. Living Qur'ān juga bisa dimaknai sebagai “teks al-Qur'ān yang 'hidup' dalam masyarakat." Pendekatan ini berusaha memotret proses interaksi masyarakat terhadap al-Qur'ān, yang tidak sebatas pada pemaknaan teksnya, tetapi lebih ditekankan pada aspek penerapan teks-teks al-Qur'ān dalam kehidupan sehari-hari. Penerapan teks-teks al-Qur'ān tersebut kemudian menjadi tradisi yang melembaga dalam kehidupan sehari-hari masyarakat.
\end{abstract}

Keywords: Living Qur'ān, interaksi sosial, tradisi, komunitas.

${ }^{1}$ Dosen Jurusan Ilmu Al-Qur'an dan Tafsir IAIN Syekh Nurjati Cirebon. E-mail: didijunaedi_hz@yahoo.com. 


\section{Pendahuluan}

Dialektika antara al-Qur'ān dengan realitas akan melahirkan beragam penafsiran. Ragam penafsiran ini pada gilirannya akan menghadirkan wacana (discourse) dalam ranah pemikiran, serta tindakan praksis dalam realitas sosial. ${ }^{2}$

Farid Esack dalam buknya The Qur'ān: a Short Introduction menegaskan, "Al-Qur'ān fulfills many of function in lives of muslims"’ Pendapat ini benar adanya. Al-Qur'ān memang mampu memenuhi banyak fungsi dalam kehidupan umat Muslim.

Dalam ranah publik, al-Qur'ān bisa berfungsi sebagai pengusung perubahan, pembebas masyarakat tertindas, pencerah masyarakat dari kegelapan dan kejumudan, pendobrak sistem pemerintahan yang zalim dan amoral, penebar semangat emansipasi serta penggerak transformasi masyarakat menuju kehidupan yang lebih baik.

Sedangkan dalam ranah privat, al-Qur'ān bisa menjadi shifă' (obat, penawar, pemberi solusi) untuk pribadi yang tengah dirundung kesedihan, ditimpa musibah, serta didera persoalan hidup.

Dalam hal ini, ayat-ayat al-Qur'ān berfungsi sebagai terapi psikis, penawar dari persoalan hidup yang dialami seseorang. Jiwa yang sebelumnya resah dan gelisah menjadi tenang dan damai ketika membaca dan meresapi makna ayat-ayat tersebut.

Di sisi lain, ada juga yang menjadikan surat atau ayat tertentu sebagai shifa', atau obat dalam arti yang sesungguhnya, yaitu untuk mengobati penyakit fisik. Salah satu ayat yang diyakini dapat menjadi obat untuk me-ruqyah orang yang sakit adalah surat al-Fatihah.

Hal ini didasarkan atas sebuah hadis sahih yang diriwayatkan oleh Imām

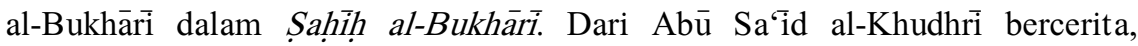
"Beberapa sahabat Nabi Muhammad Saw. mengadakan perjalanan hingga sampai suatu daerah perkampungan Arab. Mereka kemudian meminta agar suku di situ menerima mereka sebagai tamu. Tetapi, permintaan itu ditolak. Tidak lama kemudian, sang kepala suku tiba-tiba terkena sengatan hewan berbisa. Semua penduduk telah berusaha keras untuk menyembuhkannya, tetapi gagal. Sebagian dari mereka mengatakan (kepada lainnya), "Coba kalian pergi menemui orang-orang yang menginap di dusun ini! Siapa tahu, salah satu dari mereka bisa mengobati. Mereka segera pergi menemui para sahabat Nabi Saw.

\footnotetext{
${ }^{2}$ Didi Junaedi, “Memahami Teks, Melahirkan Konteks" dalam Journal of Qur'an and Hadith Studies, Vol. 2, No. 1, (2013): 3.

${ }^{3}$ Farid Esack, The Qur'an: a Short Introduction (London: Oneworld Publication, 2002), 16 .
} 
dan berkata: "Kepala suku kami terkena sengatan binatang berbisa dan kami telah berusaha dengan segala cara, namun tetap saja gagal. Apakah di antara kalian ada yang bisa mengobati?" Salah seorang sahabat Nabi Saw. menjawab: "Iya." Demi Allah, saya bisa meruqyah, namun karena kalian telah enggan menjamu kami sebagai tamu, saya tidak akan meruqyah pemimpin kalian kecuali jika diberi upah." Mereka setuju dengan tawaran itu, yakni dengan membayarkan sebagian domba mereka. Kemudian, sahabat tadi membaca surat al-Fātiḥah. Tak lama kemudian, sang kepala suku langsung sehat seolah ia tak pernah sakit. Suku itu membayar para sahabat sesuai perjanjian. Sebagian sahabat mengusulkan agar sekawanan domba itu dibagi bersama. Tetapi, sahabat yang meruqyah tadi melarang dan berkata: "Kita tidak akan membagibaginya sebelum kita menemui Nabi Saw. lalu menceritakan kejadian ini dan menunggu perintah beliau." Akhirnya, mereka menemui Nabi Saw. dan menceritakan kejadian itu kepada beliau. Rasulullah Saw. bertanya, "Bagaimana engkau tahu bahwa surat al-Fātihah dapat dibacakan sebagai ruqyah? Kalian telah melakukan hal yang benar. Sekarang, bagilah dan berikanlah jatah untukku!"4

Dalam riwayat lain, Nabi Muhammad Saw. juga pernah meruqyah dirinya sendiri dengan membaca surat al-Mu'awwidhatain, yaitu surat al-Falaq dan al-Nās ketika beliau sedang sakit. ${ }^{5}$

Dari beberapa keterangan riwayat hadis di atas, dapat dipahami jika kemudian berkembang pemahaman di masyarakat tentang fadilah atau khasiat serta keutamaan surat-surat tertentu atau ayat-ayat tertentu di dalam al-Qur'ān sebagai obat dalam arti yang sesungguhnya, yaitu untuk menyembuhkan penyakit fisik.

Di samping beberapa fungsi tersebut, al-Qur'ān juga tidak jarang digunakan masyarakat untuk menjadi solusi atas persoalan ekonomi, yaitu sebagai alat untuk memudahkan datangnya rezeki.

Lazim kita jumpai dalam fenomena yang terjadi sehari-hari di masyarakat kita, bahwa ada surat-surat atau ayat-ayat tertentu di dalam alQur'ān yang diyakini dapat memancing hadirnya rezeki, mendatangkan kemuliaan serta berkah bagi orang yang membacanya.

Keyakinan semacam ini pada gilirannya akan melahirkan tradisi membaca surat tertentu pada waktu-waktu tertentu, baik dilakukan secara

\footnotetext{
${ }^{4}$ Imām al-Bukhārì, Ṣạịḥ al-Bukhārī, Bāb al-Raqā bi Fātị̣at al-Kitāo, CD Rom, Maktabah al-Shāmilah, al-Isdà̀r al-Thānì, t.t.

5 Imām al-Bukhārì, Sahịh al-Bukhārī, Bāb al-Raqā bi al-Qur'ān, CD Rom, Maktabah al-Shāmilah, al-Isdà̀r al-Thānì, t.t.
} 
pribadi oleh individu-individu di dalam masyarakat, maupun secara kolektif yang kemudian menjadi ketentuan suatu lembaga bagi para anggotanya. Dalam hal ini, lembaga yang lazim memberlakukan ketentuan tersebut adalah pesantren.

Salah satu pesantren yang memberlakukan ketentuan berupa ritual pembacaan surat tertentu, yakni al-Wāqi'ah setiap hari oleh para ustadz dan santri, pada waktu tertentu adalah Pondok Pesantren As-Siraj Al-Hasan Desa Kalimukti Kec. Pabedilan Kabupaten Cirebon, Jawa Barat.

Menurut penuturan salah seorang ustadz yang juga pengurus pesantren tersebut, ritual pembacaan surat al-Wāqi'ah itu dilakukan setiap hari pada waktu tertentu, dengan jumlah bilangan tertentu, dengan tujuan tertentu.

Tradisi yang berjalan di Pondok Pesantren As-Siraj Al-Hasan Desa Kalimukti Kec. Pabedilan Kabupaten Cirebon ini, dalam ranah studi al-Qur'ān bisa dikategorikan sebagai Living Qur'ān (al-Qur'ān yang hidup dalam praktek sehari-hari).

\section{Penjelasan Istilah}

Ditinjau dari segi bahasa, Living Qur'ān adalah gabungan dari dua kata yang berbeda, yaitu living, yang berarti 'hidup' dan Qur'ān, yaitu kitab suci umat Islam. Secara sederhana, istilah Living Qur'ān bisa diartikan dengan “(Teks) Al-Qur'ān yang hidup di masyarakat."6

Living Qur'ān pada hakekatnya bermula dari fenomena Qur'ān in Everyday Life, yakni makna dan fungsi al-Qur'ān yang riil dipahami dan dialami masyarakat muslim. ${ }^{7}$ Dengan kata lain, memfungsikan al-Qur'ān dalam kehidupan praksis di luar kondisi tekstualnya. Pemfungsian al-Qur'ān seperti ini muncul karena adanya praktek pemaknaan al-Qur'ān yang tidak mengacu pada pemahaman atas pesan tekstualnya, tetapi berlandaskan anggapan adanya "fadhilah" dari unit-unit tertentu teks al-Qur'ān, bagi kepentingan praksis kehidupan keseharian umat. ${ }^{8}$

Heddy Shri Ahimsa-Putra mengklasifikasikan pemaknaan terhadap Living Qur'ān menjadi tiga kategori. Pertama, Living Qur'ān adalah sosok Nabi Muhammad Saw. yang sesungguhnya. Hal ini didasarkan pada keterangan dari Siti Aisyah ketika ditanya tentang akhlak Nabi Muhammad Saw., maka beliau

${ }^{6}$ Sahiron Syamsuddin, "Ranah-ranah Penelitian dalam Studi al-Qur'an dan Hadis," dalam Sahiron Syamsuddin (ed.), Metode Penelitian Living Qur'an dan Hadis (Yogyakarta: Teras, 2007), xiv.

${ }^{7}$ M. Mansur, "Living Qur'an dalam Lintasan Sejarah Studi Al-Qur'an," dalam Sahiron Syamsuddin (ed.), Metode Penelitian Living Qur'an dan Hadis, 5.

${ }^{8}$ Mansur, "Living Qur'an dalam Lintasan Sejarah Studi Al-Qur'an," 5. 
menjawab bahwa akhlaq Nabi Saw. adalah al-Qur'ān. Dengan demikian Nabi Muhammad Saw. adalah "al-Qur'ān yang hidup," atau Living Qur'ān. Kedua, ungkapan Living Qur'ān juga bisa mengacu kepada suatu masyarakat yang kehidupan sehari-harinya menggunakan al-Qur'ān sebagai kitab acuannya. Mereka hidup dengan mengikuti apa-apa yang diperintahkan al-Qur'ān dan menjauhi hal-hal yang dilarang di dalamnya, sehingga masyarakat tersebut seperti “al-Qur'ān yang hidup", al-Qur'ān yang mewujud dalam kehidupan sehari-hari mereka. Ketiga, ungkapan tersebut juga dapat berarti bahwa alQur'ān bukanlah hanya sebuah kitab, tetapi sebuah "kitab yang hidup", yaitu yang perwujudannya dalam kehidupan sehari-hari begitu terasa dan nyata, serta beraneka ragam, tergant ung pada bidang kehidupannya. ${ }^{9}$

Dalam kaitannya dengan tulisan ini, Living Qur'ān adalah kajian atau penelitian ilmiah tentang berbagai peristiwa sosial terkait dengan kehadiran alQur'ān atau keberadaan al-Qur'ān di sebuah komunitas muslim tertentu. ${ }^{10}$

Dari pengertian di atas, dapat disimpulkan bahwa Living Qur'ān adalah suatu kajian ilmiah dalam ranah studi al-Qur'ān yang meneliti dialektika antara al-Qur'ān dengan kondisi realitas sosial di masyarakat. Living Qur'ān juga berarti praktek-praktek pelaksanaan ajaran al-Qur'ān di masyarakat dalam kehidupan mereka sehari-hari. Seringkali praktek-praktek yang dilakukan masyarakat, berbeda dengan muatan tekstual dari ayat-ayat atau surat-surat alQur'ān itu sendiri.

\section{Sekilas Sejarah Living Qur'ān}

\section{Tipologi Interaksi Masyarakat dengan Al-Qur'ān}

Sebelum mengkaji lebih jauh tentang sejarah Living Qur'ān, penulis ingin menguraikan terlebih dahulu proses interaksi umat manusia dengan alQur'ān. Dalam hal ini, penulis meminjam tipologi dua orang sarjana muslim yang telah memetakan interaksi umat manusia dengan al-Qur'ān, yaitu Fazlur Rahman dan Farid Esack.

Fazlur Rahman, intelektual muslim berkebangsaan Pakistan yang wafat pada 1988, memetakan interaksi manusia dengan al-Qur'ān dengan menggunakan analogi sebuah negara. Menurut Rahman, ada tiga kelompok besar pengkaji al-Qur'ān, yakni citizens (penduduk asli, umat Islam), foreigners

9 Heddy-Shri-Ahimsa-Putra, “The Living Al-Qur'an: Beberapa Perspektif Antropologi," dalam Jurnal Walisongo 20, 1 (Mei 2012): 236-237.

${ }^{10}$ Mansur, "Living Qur'an dalam Lintasan Sejarah Studi Al-Qur'an,” 8. 
(kelompok asing/non-muslim yang mengkaji al-Qur'ān) dan invanders (penjajah, kelompok yang ingin menghancurkan al-Qur'ān). ${ }^{11}$

Farid Esack memetakan interaksi manusia dengan al-Qur'ān dengan menggunakan analogi pencinta dan kekasihnya. Pemetaan ini tidak berpretensi untuk menilai bahwa cara interaksi suatu kelompok tertentu itu lebih baik daripada kelompok yang lain. Pemetaan ini hanyalah sebuah deskripsi umum saja.

Dalam buku The Qur'ān: A Short Introduction, Esack mengkategorisasikan pembaca teks Al-Qur'ān -yang kemudian ia sebut pencinta-- menjadi tiga tingkatan: pencinta tak kritis (the uncritical lover), pencinta ilmiah (the scholarly lover), dan pencinta kritis (the critical lover). Tiga stratifikasi itu dibangun Esack dengan menggunakan analogi hubungan the lover and body of a beloved (pencinta dan tubuh seorang kekasih). The lover dan body of a beloved, masing-masing diwakili pembaca teks Al-Qur'ān dan teks Al-Qur'ān. ${ }^{12}$

Pertama, pencinta tak kritis (the uncritical lover). Pada kategori pertama ini, sang pencinta begitu terpesona dengan "kecantikan" wajah sang kekasih, sehingga tidak ada sedikit pun ruang yang mampu dia kritisi. Dia menganggap bahwa apa yang ada dalam diri kekasihnya itu adalah yang terbaik dari semua yang ada. Tidak ada yang lebih cantik dan lebih mempesona daripada kekasihnya.

Dalam konteks pembaca al-Qur'ān, pencinta tak kritis selalu meyanjung, memuji dan memuja al-Qur'ān. Baginya, al-Qur'ān adalah segala-galanya. AlQur'ān adalah 'sosok' suci yang tak boleh dipertanyakan apalagi dikritisi. Dalam pandangannya, al-Qur'ān adalah solusi atas setiap masalah, jawaban atas seluruh persoalan. Meskipun ia sendiri tidak pernah tahu bagaimana proses untuk memperoleh jawaban tersebut. Singkatnya, bagi pencinta tak kritis ini, alQur'ān diposisikan pada suatu tempat yang sangat tinggi. Sehingga, seringkali karena tingginya posisi al-Qur'ān tersebut, ia tidak dapat menjangkau makna terdalam yang sangat berharga dari al-Qur'ān tersebut.

Mereka juga menggunakan al-Qur'ān dalam beragam aspek kehidupan, seperti menggunakan ayat tertentu untuk pengobatan, penyemangat hidup, penghindar dari bahaya dan sebagainya. ${ }^{13}$

11 Sulayman Nyang, Observing the Observer the State of Islamic Studies in American Universities (Herndon: IIIT, 2012), 53. 2002).

${ }^{12}$ Farid Esack, The Qur'an A Short Introduction (London: Oneworld Publication,

${ }^{13}$ Esack, The Qur'an A Short Introduction, 2. 
Kedua, pencinta ilmiah (the scholarly lover). Kategori kedua ini adalah mereka, yang meskipun mencintai sang kekasih, tetapi tetap bersifat rasional. Mereka, dengan kecerdasan yang dimilikinya berusaha untuk tidak 'cinta buta' kepada sang kekasih. Ada ruang untuk melihat lebih jauh sang kekasih dengan mengajukan sejumlah pertanyaan, untuk memastikan bahwa kekasihnya tersebut memang layak untuk dicintai.

Dalam ranah al-Qur'ān, sang pencinta model kedua ini adalah mereka yang terpesona dengan keindahan al-Qur'ān, tetapi tidak menjadikan mereka lupa untuk mengkaji lebih jauh aspek keindahan atau mukjizat al-Qur'ān tersebut dari sisi ilmiah. Mereka, dengan kecerdasan dan kemampuan intelektual yang mereka miliki, berusaha untuk mengkaji al-Qur'ān secara ilmiah. Sejumlah pertanyaan pun diajukan untuk meneliti sisi $i^{\prime}{ }^{\prime}{ }^{\prime} z$ atau keistimewaan al-Qur'ān. Mereka mengkaji tentang aspek keindahan al-Qur'ān, baik dari sisi bahasa, susun redaksi kalimatnya, sejarahnya, hingga isyaratisyarat ilmiah yang terkandung di dalamnya.

Hasil dari kajian ilmiah tersebut kemudian mereka tuangkan dalam karya-karya ilmiah seperti tafsir serta buku-buku ilmiah lainnya yang mengkaji al-Qur'ān. Mereka yang melakukan hal ini, misalnya: Jalāl al-Dīn Al-Suyūṭi, Badr al-Dīn Al-Zarkashī, Al-Dhahabì, Husain Ṭabātabā'i, dan sejumlah ilmuan muslim lainnya.

Ketiga, pencinta kritis (the critical lover). Kategori ketiga ini adalah mereka yang meski terpesona dengan kekasihnya, sangat mencintainya, tetapi tetap kritis untuk mempertanyakan hal-hal yang dianggap 'janggal' dalam diri kekasihnya. Kecintaannya kepada sang kekasih tidak membuatnya 'gelap mata'. Mereka akan mencari tahu hal-hal yang membuat mereka terpesona, juga yang membuat mereka 'mengernyitkan dahi'. Hal ini mereka lakukan karena rasa cinta yang begitu mendalam kepada sang kekasih.

Sang pencinta yang kritis akan memosisikan al-Qur'ān tidak sekedar sebagai kekasih yang sempurna tanpa cela, tetapi menjadikannya objek kajian yang sangat menarik. Demi mengetahui banyak hal yang ada dalam al-Qur'ān, sang pencinta mau menggunakan perangkat ilmiah modern seperti hermeneutika, linguistik, antropologi, sosiologi, psikologi, bahkan filsafat sebagai pisau analisisnya.

Melalui metode seperti inilah para pencinta ini bisa mengkaji lebih dalam makna yang tersirat dalam diri kekasihnya, yaitu al-Qur'ān. Dari hasil kajian itu kemudian dituangkan dalam bentuk karya ilmiah yang 'fresh from the oven'. Sebuah hasil studi pemikiran yang segar dan mampu berdialektika, bahkan menjawab tantangan dan problematika zaman. Mereka yang masuk 
dalam kelompok ini antara lain: Fazlur Rhaman, Nasr Hamid Abu Zaid, Muhammad Arkoun, Farid Esack, Amina Wadud dan lain-lain.

Kategori berikutnya adalah berkaitan dengan interaksi non-muslim terhadap al-Qur'ān. Esack membagi tiga kelompok besar berkaitan hal ini:

Pertama, The Friend of Lover, teman pencinta, yakni peneliti nonmuslim (outsider) yang cukub 'baik' dan 'objektif' mengkritisi al-Qur'ān dengan ragam pendekatan serta memberikan kontribusi yang berharga bagi umat Islam. Sejumlah sarjana non-Muslim yang memiliki pandangan yang simpatik, meskipun kritis terhadap al-Quran dan juga Islam, seperti William Montgomery Watt, Wilfred C. Smith, William A. Graham, Kenneth Cragg.

Kedua, The Voyeur, pengintai atau mata-mata, yakni peneliti nonmuslim yang mengkritisi al-Qur'ān dan melemahkan al-Qur'ān-kadangkala secara membabi-buta. Namun, di saat lain, dia tetap mengakui hal-hal yang positif dari al-Qur'ān sejauh diungkapkan dengan argumentasi yang meyakinkannya. Masuk dalam kelompok ini adalah, misalnya, John Wansbrough, Michael Cook, Patricia Crone, dan Andrew Rippin.

Ketiga, The Polemicist, yakni peneliti outsider yang pandangannya tentang al-Qur'ān selalu negatif. Mereka menolak semua klaim yang mengatakan bahwa al-Qur'ān adalah wahyu Tuhan. Salah satu tokoh yang mewakili kelompok ini adalah Ibn Warraq yang menulis The Origins of the Koran: Classic Essays on Islam's Holy Book (1998) dan What the Koran Really Says: Language, Text, and Commentary (2002). ${ }^{14}$

\section{Living Qur'ān dalam Lintasan Sejarah}

Jika ditelisik secara historis, praktek memperlakukan al-Qur'ān, suratsurat atau ayat-ayat tertentu di dalam al-Qur'ān untuk kehidupan praksis umat, pada hakekatnya sudah terjadi sejak masa awal Islam, yakni pada masa Rasulullah Saw.

Sejarah mencatat, Nabi Muhammad Saw. dan para sahabat pernah melakukan praktek ruqyah, yaitu mengobati dirinya sendiri dan juga orang lain yang menderita sakit dengan membacakan ayat-ayat tertentu di dalam alQur'ān.

Hal ini didasarkan atas sebuah hadis shahih yang diriwayatkan oleh Imām al-Bukhāri dalam Sahịḥ al-Bukhārī. Dari 'Aisyah r.a. berkata bahwa Nabi

${ }^{14}$ Clinton Bennett, Muslims and Modernity: Current Debates (London: MPG Books, 2005), 105. 
Muhammad Saw. pernah membaca surat al-Mu'awwidhatain, yaitu surat alFalaq dan al-Nās ketika beliau sedang sakit sebelum wafatnya. ${ }^{15}$

Dalam riwayat lain disebutkan, bahwa sahabat Nabi pernah mengobati seseorang yang tersengat hewan berbisa dengan membaca al-Fātiḥah. ${ }^{16}$

Dari beberapa keterangan riwayat hadis di atas, menunjukkan bahwa praktek interaksi umat Islam dengan al-Qur'ān, bahkan sejak masa awal Islam, dimana Nabi Muhammad Saw. masih hadir di tengah-tengah umat, tidak sebatas pada pemahaman teks semata, tetapi sudah menyentuh aspek yang sama sekali di luar teks.

Jika kita cermati, praktek yang dilakukan Nabi Muhammad Saw. dengan membaca surat al-Mu'awwidhatain untuk mengobati sakitnya, jelas sudah di luar teks. Sebab secara semantis tidak ada kaitan antara makna teks dengan penyakit yang diderita oleh Nabi Muhammad Saw. Demikian juga halnya dengan praktek yang dilakukan oleh sahabat Nabi yang membacakan surat alFatihah untuk mengobati orang yang terkena sengatan kalajengking. Secara makna, rangkaian surat al-Fatihah sama sekali tidak ada kaitannya dengan sengatan kalajengking.

Dari beberapa praktek interaksi umat Islam masa awal, dapat dipahami jika kemudian berkembang pemahaman di masyarakat tentang fadilah atau khasiat serta keutamaan surat-surat tertentu atau ayat-ayat tertentu di dalam alQur'ān sebagai obat dalam arti yang sesungguhnya, yaitu untuk menyembuhkan penyakit fisik.

Di samping beberapa fungsi tersebut, al-Qur'ān juga tidak jarang digunakan masyarakat untuk menjadi solusi atas persoalan ekonomi, yaitu sebagai alat untuk memudahkan datangnya rezeki.

\section{Metode Penelitian Living Qur'ān}

Dalam ranah studi al-Qur'ān, metode penelitian living Qur'ān bisa disebut sebagai metode yang relatif baru. Sehingga, secara konseptual metode ini masih mencari bentuk untuk dapat dijadikan semacam acuan.

Living Qur'ān adalah studi tentang al-Qur'ān, tetapi tidak bertumpu pada eksistensi tekstualnya, melainkan studi tentang fenomena sosial yang lahir

15 Imām al-Bukhārī, Șậịh al-Bukhārīi, Bāb al-Raqā bi al-Qur'ān, CD Rom, Maktabah al-Shāmilah, al-Issdàr al-Thānī, t.t.

${ }^{16}$ Imām al-Bukhārì, Sahịh al-Bukhārī, Bāb al-Raqā bi Fātị̣at al-Kitāb, CD Rom, Maktabah al-Shāmilah, al-Ișdàr al-Thānī, t.t. 
terkait dengan kehadiran al-Qur'ān dalam wilayah geografi tertentu dan mungkin masa tertentu pula. ${ }^{17}$

Sebagai kajian yang berangkat dari fenomena sosial, maka pendekatan sosiologi dan fenomenologi dapat ditawarkan dalam metode living Qur'ān ini. Meskipun demikian, bukan berarti hanya pendekatan sosiologi dan fenomenologi yang bisa menjadi pisau analisis dalam penelitian living Qur'ān ini, tetapi pendekatan-pendekatan ilmiah lainnya juga bisa diterapkan dalam penelitian ini, seperti antropologi, psikologi dan beberapa pendekatan ilmiah lainnya.

Dalam prakteknya, ada beberapa metode yang bisa digunakan dalam penelitian living Qur'ān ini. Beberapa metode tersebut antara lain:

\section{Observasi}

Dalam melakukan penelitian, observasi adalah salah satu cara untuk memperoleh data dengan akurat. Secara umum, observasi diartikan dengan pengamatan atau penglihatan. Adapun secara khusus, observasi dimaknai dengan mengamati dalam rangka memahami, mencari jawaban, serta mencari bukti terhadap fenomena sosial tanpa mempengaruhi fenomena yang diobservasi. ${ }^{18}$

Observasi adalah mengumpulkan data langsung dari lapangan. Data yang diobservasi bisa berupa gambaran tentang sikap perilaku, serta tindakan keseluruhan interaksi antar manusia. ${ }^{19}$ Data observasi bisa juga hanya terbatas pada interaksi antar masyarakat tertentu.

Proses observasi dimulai dengan mengidentifikasi tempat yang akan diteliti. Dilanjutkan dengan pemetaan, sehingga diperoleh gambaran umum tentang sasaran penelitian. Kemudian menentukan siapa yang akan diobservasi, kapan, berapa lama dan bagaimana. ${ }^{20}$

Dalam ranah penelitian living Qur'ān ini, metode observasi memegang peranan yang sangat penting, yang akan memberikan gambaran situasi riil yang ada di lapangan (baca: lokasi penelitian).

${ }^{17}$ Muhammad Yusuf, "Pendekatan Sosiologi dalam Penelitian Living Qur'an," dalam Sahiron Syamsuddin (ed.), Metode Penelitian Living Qur'an dan Hadis (Yogyakarta: Teras, 2007), 39.

18 Imam Suprayogo dan Tobroni, Metodologi Penelitian Sosial-Agama (Bandung: PT. Remaja Rosdakarya, 2003), 167.

19 J.R. Raco, Metode Penelitian Kualitatif: Jenis, Karakteristik dan Keunggulannya (Jakarta: Grasindo ), 112.

${ }^{20}$ Raco, Metode Penelitian Kualitatif, 112. 
Bungin mengemukakan beberapa bentuk observasi yang dapat digunakan dalam penelitian kualitatif, yaitu observasi partisipasi, observasi tidak terstruktur, dan observasi kelompok tidak terstruktur. ${ }^{21}$

Observasi partisipasi (participant observation) adalah metode pengumpulan data yang digunakan untuk menghimpun data penelitian melalui pengamatan dan pengindraan dimana observer atau peneliti benar-benar terlibat dalam keseharian responden.

Observasi tidak berstruktur adalah observasi yang dilakukan tanpa menggunakan guide observasi. Pada observasi ini peneliti atau pengamat harus mampu mengembangkan daya pengamatannya dalam mengamati suatu objek.

Observasi kelompok adalah observasi yang dilakukan secara berkelompok terhadap suatu atau beberapa objek sekaligus.

Dalam hal ini, peneliti bisa menjadi observer yang aktif. Artinya, peneliti bisa menjadi bagian dalam kegiatan yang dilakukan oleh masyarakat yang menjadi objek penelitian. Dengan cara seperti ini, maka peneliti akan leluasa dalam memperoleh data penelitian, karena telah dianggap sebagai bagian dari masyarakat yang menjadi objek penelitian. Keberadaan peneliti tidak akan dicurigai atau dikhawatirkan mengganggu praktek atau ritual yang dilakukan oleh masyarakat setempat.

\section{Wawancara}

Wawancara adalah cara pengumpulan data dengan jalan tanya jawab dengan pihak terkait yang dikerjakan secara sistematis dan berlandaskan kepada tujuan peneliti. ${ }^{22}$

Metode wawancara dalam penelitian living Qur'ān adalah suatu yang niscaya. Seorang peneliti tidak akan mendapatkan data yang akurat dari sumber utamanya, jika dalam penelitian tentang aktivitas yang berkaitan dengan fenomena living Qur'ān di suatu komunitas tertentu, tidak melakukan wawancara dengan para presponden atau partisipan.

Dalam penelitian living Qur'ān yang bertujuan untuk mengetahui fenomena interaksi masyarakat dengan al-Qur'ān, maka metode wawancara ini mutlak diperlukan.

Jika seorang penliti ingin melakukan penelitian tentang praktek pembacaan surat tertentu di dalam al-Qur'ān, yang dilakukan suatu komunitas masyarakat tertentu, maka seorang peneliti dalam melakukan wawancara

${ }^{21}$ Burhan Bungin, Penelitian Kualitatif(Jakarta: Prenada Media Group, 2007), 115.

\footnotetext{
${ }^{22}$ Marzuki, Metodologi Riset (Yogyakarta: BPFE, 1998), 62.
} 
dengan para responden dan partisipan yang terlibat langsung dalam pelaksanaan ritual tersebut.

Peneliti bisa menanyakan tentang apa latar belakang ritual pembacaan surat tertentu dalam al-Qur'ān itu, apa motivasinya, kapan pelaksanaannya, berapa kali dibaca, siapa pesertanya, bagaimana prosesi ritualnya, dari mana sumber dananya, apa faktor pendukung dan penghambatnya, serta bagaimana pengaruhnya dalam kehidupan sehari-hari dan pertanyaan-pertanyaan lainnya yang relevan dengan maksud dan tujuan peneltian.

Untuk mendapatkan jawaban yang akurat dan valid, maka seorang peneliti harus memilah dan menentukan tokoh-tokoh kunci (key persons) yang akan diwawancarai. Mereka inilah yang dianggap memiliki data yang akurat dan valid tentang ritual yang menjadi objek penelitian kita. Mereka bisa para tokoh agama, tokoh masyarakat, sesepuh, pendiri kegiatan, pengurus kegiatan ritual tersebut, juga para jamaah yang mengikuti kegiatan tersebut.

\section{Dokumentasi}

Metode dokumentasi merupakan suatu cara pengumpulan data dengan menghimpun dan menganalisis dokumen-dokumen, baik dokumen tertulis, gambar maupun elektronik. ${ }^{23}$

Penelitian living Qur'ān tentang fenomena ritual keagamaan yang terjadi di masyarakat akan semakin kuat jika disertai dengan dokumentasi. Dokumentasi yang dimaksud bisa berupa dokumen yang tertulis, seperti agenda kegiatan, daftar hadir peserta, materi kegiatan, tempat kegiatan dan sebagainya, bisa juga berupa dokumen yang tervisualisasikan, seperti foto kegiatan atau rekaman dalam bentuk video, atau juga berupa audio.

Dengan melihat dokumen yang ada, maka peneliti bisa melihat perkembangan kegiatan tersebut dari waktu ke waktu, sehingga dapat dianalisa bagaimana respon masyarakat dengan kegiatan ritual tersebut.

\section{Urgensi Penelitian Living Qur'ān}

Selama ini kajian tentang al-Qur'ān lebih ditekankan pada aspek tekstual daripada kontekstual. Dari hasil kajian ini kemudian bermunculan karya berupa tafsir maupun buku yang ditulis oleh para pengkaji al-Qur'ān tersebut. Mainstream kajian al-Qur'ān selama ini memberi kesan bahwa tafsir dipahami harus sebagai teks yang tersurat dalam karya para ulama dan sarjana muslim. Padahal, kita semua mafhum bahwa al-Qur'ān tidak terbatas pada teks semata,

${ }^{23}$ Nana Syaodih Sukmadinata, Metode Penelitian Pendidikan (Bandung: PT. Remaja Rosdakarya, 2007), 221. 
tetapi ada konteks yang melingkupinya. Dengan demikian, maka sesungguhnya penafsiran itu bisa berupa tindakan, sikap serta perilaku masyarakat yang merespon kehadiran al-Qur'ān sesuai dengan tingkat pemahamannya masingmasing.

Respon masyarakat terhadap ajaran-ajaran serta nilai-nilai al-Qur'ān yang kemudian mereka aplikasikan dalam kehidupan sehari-hari, masih kurang mendapat perhatian dari para pengkaji al-Qur'ān. Pada titik inilah kajian serta penelitian living Qur'ān menemukan relevansi serta urgensinya. Kajian dalam bidang living Qur'ān ini memberikan kontribusi yang signifikan bagi pengembangan studi al-Qur'ān.

Penelitian living Qur'ān juga sangat penting untuk kepentingan dakwah dan pemberdayaan masyarakat, sehingga mereka lebih maksimal dalam mengapresiasi al-Qur'ān. ${ }^{24}$

Urgensi kajian living Qur'ān lainnya adalah menghadirkan paradigma baru dalam kajian al-Qur'ān kontemporer, sehingga studi al-Qur'ān tidak hanya berkutat pada wilayah kajian teks. Pada wilayah living Qur'ān ini kajian tafsir akan lebih banyak mengapresiasi respons dan tindakan masyarakat terhadap kehadiran al-Qur'ān, sehingga tafsir tidak lagi bersifat elitis, melainkan emansipatoris yang mengajak partisipasi masyarakat. ${ }^{25}$

\section{Langkah-Langkah Penelitian Living Qur'ān}

Kajian living Qur'ān berusaha memotret fenomena sosial berupa prakatek keagamaan dalam sebuah masyarakat yang didasarkan atas pemahamannya terhadap al-Qur'ān. Dengan kata lain, praktek-praktek ritual keagamaan berupa pembacaan surat atau ayat tertentu, misalnya, yang dilakukan oleh suatu masyarakat berdasarkan keyakinan mereka yang bersumber dari hasil interaksi mereka dengan al-Qur'ān

Karena yang dikaji dalam living Qur'ān ini berupa fenomena sosial, maka model penelitian yang dipakai adalah model penelitian sosial. Dalam hal ini, metode penelitian kualitatif lebih tepat digunakan dalam kajian living Qur'ān ini.

Untuk itu, maka langkah-langkah serta prosedur yang ditempuh dalam penelitian ini merujuk pada langkah-langkah serta prosedur penelitian kualitatif sebagai berikut:

24 Abdul Mustaqim, "Metode Penelitian Living Qur'an: Model Penelitian Kualitatif," dalam dalam Sahiron Syamsuddin (ed.), Metode Penelitian Living Qur'an, 69.

\footnotetext{
${ }^{25}$ Abdul Mustaqim, "Metode Penelitian Living Qur'an," 70
} 


\section{Lokasi}

Peneliti menjelaskan lokasi penelitian, yaitu dengan menyebutkan tempat penelitian, misalnya di sebuah desa, komunitas, kelompok, atau masyarakat tertentu. Berikutnya, peneliti mengungkapkan alasan tentang adanya fenomena living Qur'ān, misalnya seperti judul penelitian ini: “Living Qur'ān di Pesantren: Studi tentang Tradisi Pembacaan Surat Al-Waqi'ah di Pondok Pesantren As-Siraj Al-Hasan Desa Kalimukti Kec. Pabedilan Kabupaten Cirebon."

Selanjutnya, peneliti mengemukakan kekhasan atau keunikan lokasi penelitian tersebut, yang tidak dimiliki oleh lokasi lain berkaitan dengan tema yang akan diteliti.

\section{Metode dan Pendekatan}

Peneliti menjelaskan metode serta pendekatan yang digunakan dalam penelitian yang akan dilakukannya. Dalam contoh kasus penelitian di atas, misalnya, maka peneliti hendaknya mengungkapkan bahwa metode penelitian yang digunakan adalah kualitatif dengan menggunakan pendekatan deskriptif.

Metode kualitatif adalah metode penelitian yang ditujukan untuk memahami fenomena sosial dari sudut atau perspektif partisipan. Partisipan adalah orang-orang yang diajak berwawancara, diobservasi, diminta memberikan data, pendapat, pemikiran dan persepsinya.

Sedangkan pendekatan deskriptif adalah pendekatan penelitian yang bertujuan untuk mempelajarai secara intensif tentang latar belakang keadaan sekarang, dan interaksi lingkungan sesuatu unit sosial: individu, lembaga, kelompok atau masyarakat.

\section{Sumber Data}

Sumber data yang dimaksud adalah subjek darimana data diperoleh. Subjek atau sumber data penelitian di atas adalah:

a. Pimpinan Pondok Pesantren As-Siroj Al-Hasan

b. Pengurus Pondok Pesantren As-Siroj Al-Hasan

c. Kyai serta Ustadz di Pondok Pesantren As-Siroj Al-Hasan

d. Santri di Pondok Pesantren As-Siroj Al-Hasan

e. Masyarakat di sekitar lingkungan Pondok Pesantren As-Siroj Al-Hasan

\section{Metode Pengumpulan Data}

Untuk mendapatkan data-data yang terkait dengan tema penelitian digunakan beberapa metode pengumpulan data sebagai berikut: 

a. Observasi
b. Wawancara
c. Dokumentasi

\section{Metode Analisis Data}

Peneliti menjelaskan metode analisis data yang digunakan dalam penelitian tertsebut. Dalam contoh kasus di atas, model analisis data yang digunakan adalah model analisis interaktif (interactive model of analysis) yang meliputi tiga tahapan yaitu data reduction (reduksi data), data display (penyajian data), dan conclusion drawing (penarikan kesimpulan).

Reduksi data, yaitu proses pemilihan, pemusatan perhatian pada penyederhanaan, pengabstrakan dan transformasi data mentah atau data kasar yang muncul dari catatan-catatan tertulis di lapangan.

Penyajian data, yaitu penyusunan informasi yang kompleks ke dalam suatu bentuk yang sistematis, sehingga menjadi lebih selektif dan sederhana serta memberikan kemungkinan adanya penarikan kesimpulan data dan pengambilan tindakan.

Kesimpulan, yaitu merupakan tahap akhir dalam proses analisa data. Pada bagian ini peneliti mengutarakan kesimpulan dari data-data yang telah diperoleh dari observasi, interview, dan dokumentasi. Pada tahap ini peneliti melalukan konseptualisasi atau generalisasi.

\section{Validitas Data}

Untuk mencapai data yang valid (validitas data) dan juga kesimpulan yang valid, peneliti akan melakukan uji validitas dengan data triangulation (triangulasi data), peneliti menggunakan beberapa sumber data untuk mengumpulkan data yang sama.

Dengan langkah-langkah di atas, peneliti living Qur'ān diharapkan memperoleh deskripsi yang lengkap, mendalam, komprehensif, dan terperinci tentang masalah yang diteliti, dan selanjutnya mendapatkan kesimpulan yang bersifat induktif (empirical inductive).

\section{Hal-Hal yang Harus Diperhatikan oleh Peneliti Living Qur'ān}

Dalam penelitian living Qur'ān, ada beberapa hal yang perlu diperhatikan oleh peneliti sebagai berikut:

1. Penelitian living Qur'ān dengan menggunakan pendekatan sosiologisfenomenologis tidak berpretensi untuk menghakimi (judgment) fenomena yang terjadi dengan label 'benar'- 'salah', 'sunnah-bid'ah', 'shar'iyyah- 
ghairu shar'iyyah'. Penelitian living Qur'ān semata-mata berusaha melakukan "pembacaan" obyektif terhadap fenomena keagamaan yang berkaitan langsung dengan al-Qur'ān.

2. Living Qur'ān tidak dimaksudkan sebagai pemahaman individu atau masyarakat dalam memahami (menafsirkan) al-Qur'ān, akan tetapi bagaimana al-Qur'ān itu direspon dan dipahami masyarakat Muslim dalam realitas kehidupan sehari-hari menurut konteks pergaulan sosial dan budaya setempat.

3. Tujuan penelitian living Qur'ān adalah untuk menemukan makna dan nilainilai (meaning and values) yang melekat pada sebuah fenomena sosialkeagamaan---berupa praktek-praktek ritual yang berkaitan langsung dengan al-Qur'ān--- yang diteliti.

\section{Beberapa Contoh Karya dan Penelitian Living Qur'ān}

Dari hasil bacaan penulis terhadap sejumlah literatur tentang living Qur'ān, ada beberapa karya dan juga penelitian yang sedikit banyak berkaitan dengan kajian ini dan cukup mampu menstimulasi untuk melakukan penelitian tentang living Qur'ān lebih jauh lagi:

\section{Reading the Qur'an: The Contemporary Relevance of the Sacred Text of} Islam karya Ziauddin Sardar. ${ }^{26}$ Pada salah satu bab dalam karyanya tersebut, Ziauddin mengisahkan pengalamannya berinteraksi dengan al-Qur'ān sejak usia dini. Pada bab yang diberi judul “The Qur'ān and Me”, Ziauddin bercerita tentang masa-masa awal belajar al-Qur'am. Ketika itu usianya sekitar 7-8 tahun. Dia menceritakan bahwa ketika belajar al-Qur'ān kepada Imam Sahib, dia dan juga teman-teman sebayanya harus hati-hati dalam membaca huruf-huruf hijaiyah dalam al-Qur'ān. Ketika ada kesalahan dalam membaca huruf, atau hukum bacaan, maka akan mendapat hukuman berupa pukulan tongkat dari sang Imam. Meski demikian, semua anak yang belajar al-Qur'ān tetap rajin dan serius untuk merampungkan bacaannya hingga khatam. Saat khatam itulah, menurut Ziauddin saat-saat yang paling menyenangkan. Karena, orang tua serta keluarga anak yang mengkhatamkan al-Qur'ān akan merayakannya dengan membawa banyak makanan dan manisan sebagai ungkapan syukur dan bahagia atas khatamnya sang anak membaca al-Qur'ān. Hal ini menjadi sebuah tradisi turun temurun hingga saat ini. Fenomena yang diungkapkan oleh Ziauddin Sardar tersebut merupakan bagian dari kajian living Qur'ān.

\footnotetext{
${ }^{26}$ London: Oxford University Press, 2011.
} 
2. The Qur'ān: A Short Introduction karya Farid Esack. Dalam karyanya tersebut, Farid Esack menulis sebuah tema bahasan yang diberi judul: The Qur'ān in the Lives of Muslims. Farid menceritakan bagaimana interaksi Muslim Afrika dengan al-Qur'ān. Al-Qur'ān dibaca, dipelajari, dihafal dan dihormati sedemikian rupa. Farid juga menceritakan bahwa ketika memasak, ibunya sering menyenandungkan al-Qur'ān dengan harapan masakannya akan terasa lezat dan nikmat. Sebagian besar rumah di Afrika juga dihiasi oleh kaligrafi ayat-ayat al-Qur'ān dengan harapan rumah tersebut terjaga dari mara bahaya. Anak-anak kecil di Afrika juga membaca ayat-ayat tertentu agar tidak dikejar anjing. Beragam fenomena sosial tersebut mengantarkannya pada sebuah kesimpulan bahwa bagi Muslim al-Qur'ān itu hidup (alive) dan memiliki quasi-human personality. Pelbagai fenomena yang diungkapkan Farid ini sangat menarik untuk dikaji lebih lanjut.

3. The Qur'ān: A Biograpy karya Bruce Lawrence. ${ }^{27}$ Dalam karyanya tersebut, Bruce Lawrence mengetangahkan pengalaman sejumlah tokoh dalam berinteraksi dengan al-Qur'ān. Tokoh-tokoh tersebut antara lain: Nabi Muhammad Saw, Ja'far Shadiq, Ibn Jarir al-Thabari, Ibn 'Arabi, Jalaluddin Rumi, Robert of Ketton (penerjemah awal al-Qur'ān), Muhammad Iqbal, dan sejumlah tokoh lainnya.

4. Discovering the Qur'ān: A Contemporary Approach to A Vailed Text karya Neal Robinson. ${ }^{28}$ Pada salah satu bab dalam bukunya tersebut, Robinson menulis sebuah tema bahasan yang diberi judul: The Qur'ān as Experienced by Muslims. Bab tersebut berisi penjelasan Robonson tentang bagaimana alQur'ān diperlakukan dalam kehidupan masyarakat. Robinson mengamati banyak sekali ungkapan-ungkapan di dalam al-Qur'ān yang kemudian menjadi familiar dalam kehidupan sehari-hari, seperti ungkapan : basmalah, hamdalah, dan yang lainnya.

5. Skripsi pada UIN Sunan Kalijaga Yogyakarta pada tahun 2008, yang ditulis oleh Uswatun Hasanah dengan judul "Studi terhadap Tujuan Membaca AlQur'ān Masyarakat Dusun Sukorejo Desa Kenteng Kecamatan Susukan Kabupaten Semarang jawa Tengah.” Dalam skripsi tersebut, dijelaskan tentang beragam tujuan membaca al-Qur'ān bagi masyarakat Dusun Sukorejo, antara lain: 1). Sebagai ibadah; 2) Sebagai media pengobatan; 3) Sebagai wirid; 4) Sebagai jimat; 5) Sebagai mahabbah.

${ }^{27}$ Atlantic Monthly Press, 2006.

${ }^{28}$ Georgetown University Press, 2003. 
6. Tesis pada UIN Yogyakarta tahun 2009, yang ditulis oleh Khoirul Ulum dengan judul "Pembacaan Al-Qur'ān di Lingkungan Jawa Timur (Studi Masyarakat Grujugan Bondowoso)." Dalam tesis tersebut, Khoirul Ulum menjelaskan tentang tradisi membaca al-Qur'ān masyarakat di lokasi penelitian, yang dapat dikelompokkan menjadi dua, yaitu tradisi yang bersifat rutin, seperti Khatmil Qur'an dan Yasinan, dan tradisi yang bersifat insidental sesuai dengan kehendak sohibul hajat. Adapun tujuan pembacaanya adalah: 1) Untuk ibadah; 2) Sebagai Obat; dan 3) Sebagai perlindungan di hari akhir.

7. Artikel di Jurnal Ilmiah ADDIN Vol. 2 No. 2 Juli-Desember 2010 yang ditulis oleh Ahmad Atabik, Dosen STAIN Kudus dengan judul "The Living Qur'ān: Potret Budaya Tahfidz Al-Qur'an di Nusantara." Dalam artikel tersebut dijelaskan tentang budaya taḥfiz al-Qur'ān di Indonesia yang mulanya berasal dari pesantren, kini telah merambah ke masyarakat luar pesantren. Hal ini, menurutnya karena mulai munculnya kesadaran masyarakat muslim tentang pentingnya menghafal ayat-ayat al-Qur'ān, untuk kemudian selanjutnya memahami isinya. Dan satu hal, yang menurutnya memotivasi masyarakat muslim untuk menghafal al-Qur'ān adalah agar mendapat berkah dari al-Qur'ān.

8. Skripsi pada UIN Yogyakarta tahun 2013, yang ditulis oleh Didik Andriawan dengan judul 'Penggunaan Ayat Al-Qur'ān Sebagai Pengobatan (Studi Living Qur'ān pada Praktek Pengobatan Dr. KH. Komari Safulloh, Pesantren Sunan Kalijaga, Desa Pakuncen, Kecamatan Patianrowo, Kabupaten Nganjuk)." Dalam skripsi tersebut, Didik Andriawan menjelaskan bahwa dalam praktek pengobatan yang dilakukan oleh Dr. KH. Komari Safulloh digunakan surat-surat atau ayat-ayat tertentu di dalam alQur'ān, seperti Surat al-Fātiḥah, surat al-Ikhlāṣ, surat al-Falaq, Surat al-Nās, surat al-Baqarah: 225, surat al-Naml: 30, surat al-Ṣaffät: 79-80, dan beberapa ayat lainnya dalam al-Qur'ān, yang seringkali tidak ada kaitan antara makna ayat dengan penyakit yang diobatinya. Semua yang dilakukannya berdasarkan intuisi serta keyakinan terhadap ayat-ayat tersebut.

9. Penelitian yang dilakukan oleh Muhammad Maghfur Amin pada tahun 2013 yang berjudul 'Living Qur'ān: Tradisi Pembacaan Qolbul Qur'ān di Pesantren Miftahul Ulum Wonokerto Dusun Gresik.” Dalam penelitiannya tersebut, Maghfur Amin menjelaskan bahwa tradisi pembacaan Qalbul Qur'ān, yakni surat Yāsin di pesantren tersebut telah berlangsung puluhan tahun lamanya, yang dilaksanakan setiap malam senin. Adapun tujuan 
tradisi pembacaan surat $Y^{-}$sin tersebut adalah agar seluruh santri, ustadz serta kyai yang ada di lingkungan pesantren diberi ketenangan batin, kedamaian jiwa, dan ketentraman hati, serta keberkahan.

10. Makalah dengan judul 'The Qur'ān in Indonesian Daily Life: The Public Project of Musical Oratory," karya Anne K. Rasmussen dari College of William and May. ${ }^{29}$ Makalah ini menjelaskan tentang etnografi atau kajian kebudayaan masyarakat/komunitas pembaca al-Qur'ān di Indonesia, khususnya pembaca perempuan.

11. Penelitian yang dilakukan oleh Didi Junaedi pada tahun 2014 yang berjudul: "Living Qur'ān di Pesantren (Studi tentang Tradisi Pembacaan Surat Al-Waqiah di Pondok Pesantren As-Siroj Al-Hasan Desa Kalimukti Kec. Pabedilan Kabupaten Cirebon).” Dalam penelitiannya, Didi Junaedi menyatakan bahwa tradisi pembacaan surat al-Waqiah di pesantren tersebut sudah berlangsung puluhan tahun. Kegiatan tersebut dilakukan oleh seluruh pengurus pondok, ustadz dan para santri setiap hari (malam), yaitu pada pukul 21.30 WIB sampai selesai. Sedangkan kegiatan yang dilakukan bersama masyrakat dilaksanakan setiap senin malam pukul. 20.00 WIB sampai selesai. Adapun jumlah bacaan surat Al-Waqiah yang harus dibaca dalam pertemuan tersebut sebanyak $75 \mathrm{x}$, yaitu dibagi dengan jumlah peserta yang hadir. Hal ini didasarkan atas Ijazah--- izin mengamalkan suatu amalan berdasarkan sanad (jalur transmisi keilmuan)-- yang telah diterima pimpinan pondok dari Syekh Muhammad Fadhil alJailani (salah seorang ulama keturunan dari Syekh Abdul Qadir al-Jailani). Tujuan dari tradisi pembacaan surat Al-Waqi'ah yang dilakukan setiap hari di pesantren tersebut adalah untuk mendapatkan kelapangan rezeki, ampunan (maghfirah), serta kasih sayang (rahmat) dari Allah Swt.

\section{Contoh Hasil Penelitian Living Qur'ān}

Berdasarkan penelitian Living Qur'ān di Pesantren, yang mengkaji tentang tradisi pembacaan surat al-Waqi'ah di Pondok Pesantren As-Siroj AlHasan Desa Kalimukti Kec. Pabedilan Kabupaten Cirebon, maka dapat diambil kesimpulan sebagai berikut:

Pertama, tradisi pembacaan surat al-Waqi'ah di Pondok Pesantren AsSiroj Al-Hasan dilatar belakangi oleh beberapa hal berikut ini:

${ }^{29}$ Rasmussen, "The Qur'ān in Indonesian Daily Life: the Public Project of Musical Oratory," Ethnomusicology 45, 1 (Winter 2001): 30-57. 
1. Landasan teologis dari tradisi pembacaan surat al-Waqi'ah setiap hari di Ponpes As-Siroj Al-Hasan adalah Q.S. Al-Isra: 82 dan Q.S. Fushshilat: 44. Adapun landasan dari hadis adalah beberapa riwayat hadis tentang fadilah surat al-Waqi'ah.

2. Mengikuti tradisi para ulama Nahdlatul Ulama (NU)

3. Pimpinan Pondok Pesantren As-Siroj Al-Hasan mendapat Ijazah surat AlWaqi'ah dari Syekh Muhammad Fadil Al-Jailani, salah satu keturunan dari ulama besar, Syekh Abdul Qadir Al-Jailani.

Kedua, proses pembacaan surat Al-Waqi'ah di Ponpes As-Siroj Al-Hasan dilakukan dalam dua kategori: 1). Pembacaan surat Al-Waqi'ah yang dilakukan oleh seluruh pengurus pondok, ustadz, santri dan masyarakat di lingkungan pesantren dilaksanakan seminggu sekali, yaitu pada senin malam pukul. 20.00 WIB sampai selesai; 2). Pembacaan surat Al-Waqi'ah yang dilakukan oleh seluruh pengurus pondok, ustadz dan para santri dilakukan setiap hari (malam), yaitu pada pukul 21.30 WIB sampai dengan selesai.

Adapun jumlah bacaan surat Al-Waqiah yang harus dibaca dalam pertemuan tersebut sebanyak $75 \mathrm{x}$, yaitu dibagi dengan jumlah peserta yang hadir. Hal ini didasarkan atas Ijazah--- izin mengamalkan suatu amalan berdasarkan sanad (jalur transmisi keilmuan)--- yang telah diterima pimpinan pondok dari Syekh Muhammad Fadhil al-Jailani (salah seorang ulama keturunan dari Syekh Abdul Qadir al-Jailani).

Ketiga, tujuan dari tradisi pembacaan surat Al-Waqi'ah yang dilakukan setiap hari di Pondok Pesantren As-Siroj Al-Hasan, sebagaimana dituturkan oleh Pimpinan Pondok adalah untuk mendapatkan beberapa hal berikut ini:

1. Memperoleh kelapangan rezeki

2. Mendapatkan ampunan (maghfirah)

3. Mendapatkan kasih sayang (rahmat) dari Allah Swt.

Keempat, hasil dari tradisi pembacaan surat Al-Waqi'ah di lingkungan Pondok Pesantren As-Siroj Al-Hasan adalah sebagai berikut:

1. Bagi para santri, ustadz dan para pengasuh pesantren:

a. Mendapatkan ketenangan batin

b. Memperoleh kemudahan dan kelancaran dalam proses kegiatan belajar mengajar (KBM)

c. Menumbuhkan semangat hidup

2. Bagi masyarakat di sekitar lingkungan pesantren :

a. Merasakan kedamaian jiwa

b. Mendapatkan kelapangan rezeki

c. Memperoleh keberkahan hidup 


\section{Penutup}

Demikianlah pemaparan sekilas tentang Living Qur'ān sebagai sebuah metode baru dalam penelitian serta pengkajian al-Qur'ān. Tentu, metode ini masih jauh dari sempurna, sehingga pembenahan tentang metode ini sebagai salah satu alternatif dalam mengkaji al-Quran harus terus dilakukan.

\section{Daftar Pustaka}

Abdul Mustaqim. "Metode Penelitian Living Qur'an: Model Penelitian Kualitatif." Dalam Sahiron Syamsuddin (ed.). Metode Penelitian Living Qur'an dan Hadis. Yogyakarta: Teras, 2007.

Bennett, Clinton. Muslims and Modernity: Current Debates. London: MPG Books, 2005.

al-Bukhārì. Sahị̣h al-Bukhārī, Bāb al-Raqā bi Fātị̣at al-Kitāb, CD Rom, Maktabah al-Shāmilah, al-Isdār al-Thānī, t.t.

Bungin, Burhan. Penelitian Kualitatif. Jakarta: Prenada Media Group, 2007.

Essack, Farid. The Qur'ān: a Short Introduction. Oxford: One World Publication, 2002

Junaedi, Didi. “Memahami Teks, Melahirkan Konteks" dalam Journal of Qur'ān and Hadith Studies 2, 1 (2013).

Lawrence, Bruce.The Qur'ān: A Biograpy. Atlantic Monthly Press, 2006.

Mansur, M. 'Living Qur'an dalam Lintasan Sejarah Studi Al-Qur'an.” Dalam Sahiron Syamsuddin (ed.). Metode Penelitian Living Qur'an dan Hadis. Yogyakarta: Teras, 2007.

Marzuki. Metodologi Riset. Yogyakarta: BPFE, 1998.

Nyang, Sulayman. Observing the Observer the State of Islamic Studies in American Universities. Herndon: IIIT, 2012.

Putra, Heddy Shri Ahimsa. "The Living Al-Qur'ān: Beberapa Perspektif Antropologi." dalam Jurnal Walisongo 20, 1 (Mei 2012).

Raco, J.R. Metode Penelitian Kualitatif: Jenis, Karakteristik dan Keunggulannya. Jakarta: Grasindo.

Rasmussen, Anne K. 'The Qur'ān in Indonesian Daily Life: the Public Project of Musical Oratory." Ethnomusicology 45, 1 (Winter 2001): 30-57.

Robinson, Neal. Discovering the Qur'ān: A Contemporary Approach to A Vailed Text. Georgetown University Press, 2003. 
Didi Junaedi

Sardar, Ziauddin. Reading the Qur'an: the Contemporary Relevance of the Sacred Text of Islam. London: Oxford University Press, 2011.

Sukmadinata, Nana Syaodih. Metode Penelitian Pendidikan. Bandung: PT. Remaja Rosdakarya, 2007.

Suprayogo, Imam dan Tobroni. Metodologi Penelitian Sosial-Agama. Bandung: PT. Remaja Rosdakarya, 2003.

Syamsuddin, Sahiron (ed.) Metode Penelitian Living Qur'ān dan Hadis. Yogyakarta: Teras, 2007.

Syamsuddin, Sahiron. "Ranah-ranah Penelitian dalam Studi al-Qur'an dan Hadis." Dalam Sahiron Syamsuddin (ed.). Metode Penelitian Living Qur'an dan Hadis. Yogyakarta: Teras, 2007.

Yusuf, Muhammad. "Pendekatan Sosiologi dalam Penelitian Living Qur'an." Dalam Sahiron Syamsuddin (ed.). Metode Penelitian Living Qur'an dan Hadis. Yogyakarta: Teras, 2007. 